\title{
Responsabilidade civil em acidentes de trânsito automobilístico - aspectos relevantes da legislação, doutrina e da jurisprudência
}

\section{Civil responsibility in traffic accidents with cars - relevant aspects of legislation, doctrine and jurisprudence}

\author{
Aline Passos de Azevedo ${ }^{1}$
}

\begin{abstract}
Resumo
Abordagem sobre os aspectos relevantes e atuais sobre a responsabilidade civil em acidentes de trânsito com veículo automotor. Análise das teorias da culpa e sua aplicação pragmática. Estudo dos parâmetros de indenização, levando-se em conta os eventos externos para sua concorrência e eventual participação da vítima, com seus reflexos no quantum. Indicação sobre as causas de exclusão da responsabilidade de indenizar. Ao final, apontamentos sobre a responsabilidade civil no Código de Trânsito Brasileiro, seguindo-se das conclusões.
\end{abstract}

Palavras-chave: Acidentes. Trânsito. Responsabilidade civil. Aspectos relevantes.

\begin{abstract}
An approach concerning relevant and current aspects on civil responsibility in traffic accidents involving cars. Analysis of guilt theories and their pragmatic use. Study of the compensation parameters, taking into consideration external events for its occurrence and the victim's accidental participation, with its consequences in the quantum. Indication about the compensation responsibility exclusion causes. Notes on civil responsibility in the Brazilian Traffic Code, followed by the conclusions.
\end{abstract}

Key words: Accidents. Traffic. Civil responsibility. Relevant aspects.

\footnotetext{
Artigo científico apresentado ao curso de Pós-Graduação Lato Sensu em Direito e Processo Civil da Universidade Estadual de Londrina como requisito parcial para a obtenção do título de Especialista.
} 


\section{Introdução}

A responsabilidade civil no campo dos acidentes automobilísticos teve sua importância ampliada, tendo em vista o crescimento dos setores da indústria automotiva, associada à demanda urgente por meios de transporte cada vez mais seguros, eficientes e de baixo custo.

São carros de passeio, vans, ônibus, motocicletas, que abarrotam as avenidas das cidades e circulam em meio a pedestres, motociclistas, sinaleiros, obstáculos. Nãobastassea quantidade deinformações a serem coordenadas pelo motorista ao conduzir seu veículo num trânsito intenso, este ainda se vale de vias precárias, sem um planejamento de tráfego viário adequado, o que gera situações jurídicas das mais variadas e complexas.

Por essas razões, o número de acidentes de trânsito, tanto nas rodovias, quanto nas cidades de médio e grande porte é assustador.

Wilson Melo da Silva (1983, p. 11) relaciona as causas principais dos acidentes de trânsito de maneira singular:

[...] a falta de ajuste psicológico para a condução do veículo e a desobediência costumeira às regras e disposições regulamentares. E aduz que tais causas, na generalidade com a que são expostas, comportam desdobramentos: a embriaguez, a fadiga, o sono, o nervosismo, os estados de depressão e angústia, a emulação, o uso de drogas, o exibicionismo etc. Todas essas causas e desdobramentos evidenciam uma conduta culposa do motorista e demonstram a necessidade de serem cominadas penas mais severas aos causadores de acidentes.

Como a utilidade dos automóveis ultrapassou a necessidade de locomoção, sua perda ou deterioração gera prejuízo econômico representativo no patrimônio do proprietário, já que estes bens duráveis hoje se revestem de um caráter comercial patente, por vezes sentimental e, muitas vezes, são símbolo de status.
Além da representatividade material do bem, outros valores estão em jogo, tais como a vida, a integridade moral, corporal, estética do acidentado, também a produtividade e capacidade laboral da pessoa, que implica a sustentabilidade familiar.

Quando se tem um acidente automobilístico, podem estar presentes algumas figuras: empregador e empregado, pai e filho, proprietário e condutor, terceiros interessados ou não, seguradora e segurado, locador e locatário, etc., que se ligam pelo condão da culpa, no mais freqüente dos casos.

Muitas vezes, ignora-se a comprovação da culpa, bastando o nexo causal entre a pessoa e o dano para então surgir à responsabilidade de indenizar. Há várias modalidades ou formas diferentes de se atribuir a alguém o dever de pagar, seja por meio do cometimento de um ilícito (responsabilidade delitual: art. 186, do Código Civil), por um contrato que vinculam as partes (responsabilidade contratual), pelo poder de mando ou representação (art. 115 do Código Civil), ou ainda pelo poder familiar, curatela ou tutela (art. 932, I e II do Código Civil).

Pode-se citar a responsabilidade subjetiva (decorrente da culpa) e a objetiva (como a do Estado, regida pelo art. $37, \S 6^{\mathrm{a}}$, da Constituição Federal), ou a por fato do empregado ou preposto (art. 932, III, e 933 do Código Civil).

Lecionam ainda José de Aguiar Dias (1979, p. 28) e Caio Mário (1992, p. 122) que a doutrina brasileira em torno da responsabilidade automobilística seguiu o direito francês (Código de Napoleão, art. 1.384, $\S 2^{\circ}$ ), e toma como base a culpa ligada à "guarda da coisa". Esta estabelece a obrigação de responder pelo fato das pessoas e das coisas, muito embora se tenha construído um sistema com alicerces na jurisprudência, já que aos tribunais compete extrair dos preceitos fundamentais o pronunciamento que seja, na ocasião, o mais apto a realizar o fim de direito. 
O nosso Código adotou o princípio da culpa como fundamento da responsabilidade, muito embora haja concessões à responsabilidade objetiva, que será tratada mais adiante.

José de Aguiar Dias (1979, p. 122) descreve a culpa como uma "situação contrária ao estado de graça, que, na linguagem teológica, se atribui à alma isenta de pecado".

Verificam-se duas modalidades de culpa, quais sejam: a contratual e a extracontratual ou aquiliana. Tanto uma, quanto a outra se fundam no conceito de culpa, muito embora as regras que a lei estabelece em matéria de culpa contratual possam aplicar-se extracontratual, e vice versa.

Nos acidentes de trânsito, em geral, está presente, por vezes, tanto a responsabilidade contratual (ex. relação de transporte, de seguro, entre patrão e empregado), quanto a extracontratual (relação entre motorista e vítima, entre motorista e caronista).

Culpa designa a violação de um preceito ou dever preexistente. A culpa também se verifica na prática de uma conduta ilícita, que era previsível e evitável.

Em suma, quando o ato ilícito repercute no patrimônio material ou imaterial de outrem se concretiza a responsabilidade civil.

\section{Teorias da culpa}

\section{Teoria da culpa subjetiva}

Responder pelo dano caso haja dado causa direta a ele é a definição de culpa, em regra, adotada pelo Código Civil Brasileiro.

Diz o Código Civil, em seu artigo 927, caput: "Aquele que, por ato ilícito (arts. 186 e 187) causar dano a outrem, fica obrigado a repará-lo". (BRASIL, 2007, p. 252).

Isso significa que, uma vez verificada a existência de culpa, gera-se o dever de indenizar por parte do agente causador, mas há que estar presente o nexo causal entre sua conduta e o dano produzido.
Portanto, a culpa pode caracterizar uma negligência (omissão), imprudência (ação) e imperícia (conduta irregular no trabalho). Todas devem de serem comprovadas para que ao réu seja imputada a responsabilidade pelo dano, bem como do liame entre a conduta e o dano.

\section{Teoria da culpa objetiva ou teoria do risco}

O Código Civil consagrou a teoria do risco em seu artigo 927, parágrafo único, in fine:

Haverá obrigação de reparar o dano, independentemente de culpa, nos casos especificados em lei, ou quando atividade normalmente desenvolvida pelo autor do dano implicar, por sua natureza, risco para os direitos de outrem (BRASIL, 2007, p. 252).

Com brilhantismo Saleilles (apud DIAS, 1979, p. 63) explana os fundamentos da aplicação desta teoria:

A lei deixa a cada um a liberdade de seus atos; ela não proíbe senão aqueles que se conhecem como causa direta do dano. Não poderia proibir aqueles que apenas trazem em si a virtualidade de atos danosos, uma vez que se possa crer fundamentalmente que tais perigos possam ser evitados, à base de prudência e habilidade. Mas, se a lei os permite, impõe àqueles que tomam o risco a seu cargo a obrigação de pagar os gastos respectivos, sejam ou não resultados de culpa. Entre eles e as vítimas não há equiparação. Ocorrido o dano, é preciso que alguém o suporte. Não há culpa positiva de nenhum deles. Qual seria, então, o critério de imputação do risco? A prática exige que aquele que obtém proveito de iniciativa lhe suporte os encargos, pelo menos a título de sua causa material, uma vez que essa iniciativa constitui um fato que, em si e por si, encerra perigos potenciais contra os quais os terceiros não dispõem de defesa eficaz. É um balanceamento a fazer. A justiça quer que se faça inclinar o prato da responsabilidade para o lado do iniciador do risco.

Na teoria objetiva não há necessidade da prova da culpa. No entanto, ainda persiste a ação ou omissão 
por parte do agente causador, o dano (prejuízo) e o nexo de causalidade.

Os artigos 932 e 933 do Código Civil mencionavam algumas pessoas, tais como os pais, os professores, os patrões, aquele a quem cabe a guarda, as quais se presumem culpadas, uma vez ocorrido o fato danoso. A presunção, aí, é absoluta.

Importa dizer que não se admite que alguma dessas pessoas ofereça prova de que não praticou ato culposo; sua prova será restrita às causas de excludentes de responsabilidade: culpa exclusiva da vítima, caso fortuito e força maior.

Isto porque, nestes casos, há presunção e a culpa é dada como provada. A vítima só tem de demonstrar que o dano foi causado pela pessoa ou coisa sob guarda do réu.

Em contrapartida, só é possível ao réu produzir prova de força maior ou culpa da vítima, no intuito de se escusar da responsabilidade pelo dano. Entretanto, há julgado do Superior Tribunal de Justiça no sentido de que "o proprietário do veículo se exonera da responsabilidade pelo dano se provar que tudo fez para impedir a ocorrência do fato". (BRASIL, 2000).

Quando presente à responsabilidade objetiva, não cabe o uso do termo "culpa concorrente", já que para uma das partes não há análise de culpa. $\mathrm{O}$ que há é tão somente culpa da vítima, seja total ou parcial, pelo ato lesivo, minimizando ou excluindo a responsabilidade objetiva, o que influirá no quantum indenizatório.

A teoria do risco aplica-se também com relação ao Estado, por previsão constitucional, em seu artigo 107. O ente público é incumbido de zelar pela segurança do sistema de trânsito, além da conservação das vias de circulação, e responde pela má sinalização e buracos, por exemplo. Mas, ainda assim, pode ficar atenuada se demonstrar que também o prejudicado concorreu com culpa para o evento.

É interessante verificar a evolução do instituto da responsabilidade sem culpa, em que não só o ato ilícito ou anormal passou a gerar direito a indenização, mas qualquer ato, puro e simplesmente, contanto que tenha lesionado outrem. $\mathrm{O}$ risco da atividade é assumido pelo seu beneficiário. Se a ele é revertido o bônus, na mesma medida, o ônus, independentemente da verificação de negligência, imprudência ou imperícia nos atos perpetrados.

Com isso, vê-se a eliminação da responsabilidade delitual em privilégio da contratual, que se reverte em benefício da produção da prova pela vítima. Ora, se existe um contrato que vincula o causador do dano ao responsável legal, este, que pode ser o empregador, o transportador, o Estado, responderá independentemente de prova da culpa.

Incluir o causador do dano no pólo passivo da ação, portanto, é faculdade da vítima.

Vislumbra-se tal situação jurídica na relação passageiro/transportador, por exemplo. Aqui, o transportador assume a obrigação de conduzir o passageiro em segurança. Se não o faz, está violando o contrato e é obrigado a indenizar.

A jurisprudência excepciona a responsabilidade subjetiva em caso de transportadoras no sentido de que:

Constitui causa de excludente da responsabilidade da empresa transportadora fato inteiramente estranho ao transporte em si, como é o assalto ocorrido no interior do coletivo (BRASIL, 2002).

Entretanto, caberá sempre ação regressiva contra o causador do dano, se este agiu com dolo ou culpa (art. 735 e 934 do Código Civil).

Inclusive a seguradora tem ação regressiva contra o causador do dano pelo que efetivamente pagou, até o limite previsto no contrato de seguro ${ }^{2}$. (BRASIL, STF).

\footnotetext{
2 O segurador tem ação regressiva contra o causador do dano, pelo que efetivamente pagou, até ao limite previsto no contrato de seguro.
} 
Desse modo, na ação proposta pela vítima tão somente contra o objetivamente responsável, este poderá proceder à denunciação à lide em face daquele que estiver obrigado, pela lei ou pelo contrato, a indenizar, em ação regressiva, o prejuízo do que perder a demanda (art. 70, III, do Código de Processo Civil), evitando-se a propositura de ação própria.

Este é um caso de denunciação obrigatória. Entretanto, a jurisprudência se divide quanto às conseqüências da ausência de denunciação. Uma corrente afirma que a parte que não denunciou a lide apenas ficará sem título executivo, sem prejuízo de intentar ação contra o responsável (BRASIL, 1999); outra afirma que, à falta de denunciação, o vencido perde o direito de regresso, mas é minoritária. Prevalece a primeira corrente e, com relação ao Estado, há jurisprudência assentada do Superior Tribunal de Justiça (BRASIL, 2005).

A sentença que julgar procedente a ação declarará, conforme o caso, o direito do evicto, ou a responsabilidade por perdas e danos, valendo como título executivo (art. 76, Código de Processo Civil).

Questionamento atual se faz sobre a possibilidade de a vítima entrar com ação diretamente contra a seguradora, ou seja, contra quem está obrigado a indenizar em ação de regresso.

Há dois posicionamentos contrários dentro do Superior Tribunal de Justiça:

a. um entendendo pela possibilidade de ação direta contra o segurador, sendo irrelevante que o contrato envolva apenas o segurado causador do acidente, que se nega a usar a cobertura do seguro (BRASIL, 2000). Neste caso, a seguradora arcará com custas processuais e honorários advocatícios, em caso de sucumbência.

b. outro entendendo que a ação de responsabilidade civil deve ser proposta ao responsável pelo dano, que compete denunciar à lide o terceiro obrigado a indenizar o prejuízo (BRASIL, 1997), uma vez que o contrato de seguro prevê o reembolso ao segurado pelo que despendeu e não pagamento direito a terceiro estranho ao contrato. Uma vez aceita a denunciação, o denunciado não arca com o ônus sucumbencial (BRASIL, 2000). Se a obrigação da seguradora não cobre todo o pedido, pode recusar a denunciação nesta parte.

Mesmo na ação direta contra a seguradora, há necessidade de se fazer prova da culpa do segurado (BRASIL, 2000), porque a seguradora somente se obriga quando presente à situação do reembolso. Logo, ou o causador do dano deverá integrar o pólo passivo da ação, ou será arrolado como testemunha, a fim de ficar configurada a culpa do segurado e, em tese, a obrigação da seguradora de reembolsá-lo.

O Tribunal tem entendido pela possibilidade de condenação conjunta do segurado e seguradora, pelo que sucumbe o argumento de que a seguradora tem o dever tão somente de reembolso (BRASIL, 2000).

É importante salientar que a Súmula 246 do Superior Tribunal de Justiça pontifica que "o valor do seguro obrigatório deve ser deduzido da indenização judicialmente fixada".

\section{Teoria da culpa contra a legalidade}

Rui Stoco (2004, p. 1376) adverte para a ampliação da aplicação desta teoria, adotada por autores como Martinho Garcez Neto e Wilson Melo da Silva. Por ela entende-se que o desrespeito a uma norma regulamentar do trânsito pressupõe a culpa do agente, sem necessidade de demonstração da imprudência ou negligência. Assim, se o motorista encontrava-se acima da velocidade permitida no local quando do acidente, estava alcoolizado, sem carteira de motorista ou falando ao celular, por exemplo, caracterizada estaria a sua culpa, o que o levaria a indenizar pelos danos daí decorrentes. 


\section{Danos decorrentes de acidentes de trânsito e suas implicações}

O valor da indenização, em regra, é medido pela gravidade do dano, que pode ser desde uma lesão leve, à perda ou inutilização de membro ou morte.

Nesses casos, o juiz analisa o grau da lesividade e a possibilidade econômica do ofensor. A jurisprudência tem condenado no valor de 100 a 200 salários mínimos nos casos em que há morte, a título de indenização por danos morais, afora eventual lucro cessante, pensão e danos materiais, como despesas com hospital e funeral (art. 948 do Código Civil).

Não pode haver responsabilidade sem a existência de um dano efetivo: lesão a qualquer bem jurídico. Logo, o dano hipotético não justifica reparação. Em regra, o prejudicado deve provar o dano, não bastando indícios de um possível prejuízo. O prejuízo deve ser certo - é a regra essencial da reparação.

Encontra guarida de reparação o dano positivo (dano emergente) e o lucro frustrado (lucro cessante), em que a mera possibilidade não basta, mas também não se exige a certeza absoluta. O critério acertado está em condicionar o lucro cessante a uma probabilidade objetiva resultante do desenvolvimento normal dos acontecimentos (STOCO, 2004, p. 935).

$\mathrm{O}$ art. $5^{\circ}$ da $\mathrm{CF} / 88$ assegura o direito de indenização por dano material, moral e à imagem, que visa se possível, restaurar o statu quo ante, isto é, devolvendo-se ao estado em que se encontrava antes da ocorrência do ato ilícito.

A reparação pode ser natural, que importa na restauração do status quo alterado, mas a indenização em dinheiro, nada obstante seu caráter subsidiário, é a mais freqüente.

Uma vez fixado o valor da indenização, cumpre ao julgador igualmente fixar juros e correção monetária na sentença, que segue um critério jurisprudencial pacífico.
Conforme a Súmula 54 do STJ, "os juros moratórios fluem a partir do evento danoso, em caso de responsabilidade extracontratual", aplicando-se juros moratórios de $0,5 \%$ (meio por cento) ao mês, para o período que antecede a vigência do novo Código Civil e, a partir de 11/01/2003, incide a taxa de $1 \%$ (um por cento) ao mês.

Observe que a jurisprudência excepcionou a aplicação dos artigos 405 do Código Civil e 219, caput, do Código de Processo Civil, para casos de responsabilidade extracontratual, pelo que os juros não contam da citação da inicial, mas da data do evento danoso.

Com respeito à correção monetária, Súmula 43 do STJ diz: "incide correção monetária sobre dívida por ato ilícito a partir da data do efetivo prejuízo". Como a correção monetária possui o objetivo da manutenção do poder de compra da moeda ao longo do tempo, sua incidência não é quando da prolação da decisão, mas sim, em se tratando de danos materiais, da data do efetivo prejuízo acarretado ao autor, vale dizer, no dia do acidente automobilístico.

Quando se tratar de danos morais, este sim fluirá a partir da sentença.

Se cada litigante for em parte vencedor e vencido, os ônus de sucumbência devem ser suportados proporcionalmente entre os litigantes (art. 21, CPC).

É importante salientar que o Código Civil trouxe um artigo inovador, sem correspondência com o Código de 1916, que dá uma abordagem diferenciada quanto à reparação por danos, levando em consideração o grau da culpa para redução eqüitativa da indenização. Diz o seguinte a redação no parágrafo único do artigo 944:

\footnotetext{
"Art. 944. A indenização mede-se pela extensão do dano".

"Parágrafo único. Se houver excessiva desproporção entre a gravidade da culpa e o dano, poderá o juiz reduzir, equitativamente, a indenização.”
} 
Assim, quando houver desproporção entre a gravidade da culpa (ex. culpa leve consistente em dirigir sem atenção ou sem os cuidados indispensáveis à segurança - art. 169 do Código de Trânsito Brasileiro - CTB) e o dano (ex. morte), o juiz poderá levar em conta não à gravidade do dano, mas o grau da culpa para medir a indenização.

\section{Dano material}

$\mathrm{O}$ dano material refere-se à perda patrimonial econômica do lesado, que deve ser vista sob a ótica atual e futura.

A indenização, vista sob a ótica atual, engloba despesas com medicamentos, hospital, transporte, funeral, etc., bem como com o que deixou de auferir (lucro cessante). Uma vez comprovadas essas despesas, é certo o dever de indenizar, o que dispensa maiores análises.

A ótica futura está consubstanciada no que a vítima ou seus dependentes deixará de ganhar por ocorrência de perda permanente ou temporária da aptidão laborativa do lesado. Pode-se falar em pensão, vitalícia ou por tempo determinado (art. 950, caput, do CC), ou indenização de uma só vez (art. 950, parágrafo único, CC), a depender do grau da lesão ou morte, que demanda um estudo mais pormenorizadode suas particularidades.

Comprovada a dependência financeira dos autores para com a vítima, impõe-se determinar o pagamento da pensão mensal. A pensão mensal é devida a partir da data da ocorrência do evento danoso.

Quanto ao termo final da pensão, se ocorre morte dos pais, com relação aos filhos, presume-se a cessação do auxílio aos 25 anos, sob o pressuposto de que, nesta idade, teria vida independente.

Se, no mesmo acidente, houve a morte de um dos pais e do filho, no momento em que este filho completaria 25 anos a pensão a seu favor revertese ao viúvo, menos $1 / 3$, referente a gastos pessoais da vítima. Isso porque se entende que com a independência econômica do filho em relação aos genitores, o quantum gasto com a subsistência dele se reverteria em benefício dos demais dependentes.

Nos demais casos, diante da atual expectativa de vida do brasileiro, a pensão varia na jurisprudência até a data em que a vítima completaria 65 ou 70 anos de idade.

Em caso de pensão vitalícia, da indenização calculada deve ser deduzida a habitual parte correspondente à $1 / 3$, que constituiria despesa mínima necessária para a sobrevivência do finado.

\section{Dano moral e dano estético}

$\mathrm{Na}$ fixação do dano moral, deve o magistrado levar em conta critérios de proporcionalidade e razoabilidade, atendidas as condições do ofensor, do ofendido e do bem jurídico lesado, não podendo constituir fonte de enriquecimento ilícito e tampouco representar valor ínfimo que não sirva como forma de desestímulo ao agente.

Doutrina e jurisprudência aponta para o fato de que o dano pessoal está contido no dano moral. Neste sentido, foi o entendimento do Ministro Fernando Gonçalves, ressaltando ser entendimento assentado do Superior Tribunal de Justiça - STJ: "o dano pessoal compreende o dano moral" (BRASIL, 2003), logo, é aquele que atinge um direito da personalidade, seja ele de ordem física, somática ou psíquica, de natureza patrimonial ou extrapatrimonial.

Dano estético se consubstancia no fato de ter experimentado a vítima deformidade morfológica, agravando-se se acaso dependia economicamente de sua aparência.

No que tange a cumulatividade do dano estético com o dano moral, a jurisprudência se divide, parte entendendo que o dano estético é modalidade de dano moral, parte asseverando que cada dano se presta a indenizações diferenciadas. 
Neste particular, o STJ tem sustentado que o dano estético individualiza-se do dano moral, se possível quantificar autonomamente os valores (BRASIL, 2007).

Note-se que o Superior Tribunal de Justiça admitiu a existência do dano estético e do dano moral como conceitos diversos e, em contrapartida, admitiu-os cumulativamente.

Isso importa em dizer que a discussão doutrinária não afeta o efetivo ressarcimento pela intensidade do dano, seja entendido como moral ou estético.

Cabe ao julgador entender o dano estético, em si mesmo considerado, como modalidade ou não do dano moral.

O substancial é avaliar a abrangência do dano e indenizar em grau equivalente.

Caso o magistrado entenda que o dano estético está contido no moral, ou mesmo que não há dano estético, mas somente moral, seu ressarcimento, entretanto, não significa, sempre necessariamente, o esgotamento do valor tido por devido. Neste caso, o dano moral deve ser indenizado levando-se em conta a intensidade da dor e prejuízo.

Logo, tem-se que ambas manifestações são indenizáveis. O cuidado está em não conduzir a cumulatividade a um bis in idem, insuportável ao indenizador. Isto seria atribuir ao dano moral uma dupla carga indenizatória: uma referente ao que se pode chamar de dano moral puro e outra pelo dano morfológico, e ainda onerar o ofensor com a indenização pelo dano entendido por puramente estético.

O professor Clayton Reis (2000, p. 113-114), em sua obra Avaliação do Dano Moral, traz um quadro comparativo entre os valores médios (em salários mínimos) fixados pelos Tribunais pátrios e o dano experimentado pela vítima, resultando numa verdadeira equação para o cálculo do dano moral, no entanto, a jurisprudência é oscilante.

\section{Causas atenuantes ou excludentes da responsabilidade de indenizar}

\section{Culpa concorrente}

Consiste no fato de autor e vítima terem concorrido, cada qual com sua parcela de culpa, para a ocorrência do evento danoso.

O artigo 945, que não encontra correspondência no Código Civil de 1916, enuncia:

Art. 945. Se a vítima tiver concorrido culposamente para o evento danoso, a sua indenização será fixada tendo-se em conta a gravidade de sua culpa em confronto com a do autor do dano.

Aqui o legislador adotou um critério balanceado para aferição do quantum indenizatório, tomando por base a participação de autor e vítima na dinâmica do acidente. Isso dissipa a idéia da dualidade culpada e inocente no julgamento da causa, preconizando a realidade dos fatos.

A este instituto alguns doutrinadores denominam teoria da causalidade adequada.

Se, mesmo depois de instruído o processo, ainda pairar dúvida quanto à participação ou não do ofendido no evento que lhe ocasionou prejuízos, vigora o princípio in dúbio pro creditoris, onde a atenção do julgador deve voltar-se para a vítima, ainda que se corra o risco de que o ofensor indenize mais do que era devido. Isso porque a proteção à pessoa é garantia fundamental constitucional e encontra prioridade em relação ao direito de não indenizar, pelo que não se admite a vítima receber a menor.

Em relação ao transporte de pessoas, na mesma trilha, o legislador preconiza no artigo 738, parágrafo único, do Código Civil, in fine:

Parágrafo único. Se o prejuízo sofrido pela pessoa transportada for atribuível à transgressão de normas e instruções regulamentares, o juiz reduzirá 
eqüitativamente a indenização, na medida em que a vítima houver concorrido para a ocorrência do dano.

Trata-se, pois, da culpa concorrente, causa redutiva da responsabilidade de indenizar, que depende de dilação probatória de cada uma das partes com relação ao nexo causal. Não pode, portanto, ser alegada contrarresponsabilidade objetiva.

\section{Culpa exclusiva da vítima}

Nos casos de culpa exclusiva da vítima, ensina Silvio Rodrigues (1997, p. 165-166):

Com efeito, no caso de culpa exclusiva da vítima, o agente que causa diretamente o dano é apenas um instrumento do acidente, não se podendo, realmente, falar em liame de causalidade entre seu ato e o prejuízo por aquela experimentada.

A conduta da vítima como fato gerador do dano elimina a causalidade. Realmente, se a vítima contribuiu com ato seu na construção dos elementos do dano, o direito não se pode conservar alheio a esta circunstância. Inclusive, é causa de exclusão da responsabilidade, a ser alega da provada mesmo nos casos de responsabilidade objetiva.

Rui Stoco adverte para o princípio da confiança que vigora em matéria de trânsito, exemplificando (2001, p. 1122):

Em matéria de trânsito deve vigorar sempre o princípio da confiança. O condutor de um veículo tem o direito de esperar que os outros condutores e pedestres se atenham às regras de trânsito e às cautelas que de todos são exigidas no convívio social. Se o pedestre deixa de observar as regras concernentes à normalidade da conduta, procurando atravessar a pista fora das faixas de segurança, não há como imputar culpabilidade ao condutor do veículo, que se vê surpreendido por imprevisível comportamento do pedestre, no caso de atropelamento deste.
Mas esta situação distingue-se do caso fortuito, força maior, e mesmo do fato de terceiro.

\section{Caso fortuito, força maior e fato de terceiro}

Caso fortuito e força maior são excludentes de responsabilidade por eliminação do nexo causal.

Isso significa que o autor da ação danosa não responderá perante a vítima de forma alguma, nem por intermédio de ação direta proposta contra si, nem por ação regressiva, mesmo quando presente responsabilidade objetiva.

Aliás, uma derivada de contrato com transportador (art. 734 do CC), posto que os efeitos do fato ocorrido não eram possíveis de serem evitados (art. 393 do CC).

Já o fato de terceiro corresponde a uma lesão ocorrida por culpa de terceira pessoa identificada, que não as envolvidas no acidente.

Neste caso, muito embora também haja a exclusão do nexo causal, o artigo 930 do CC determina que o agente da conduta (autor do dano) responda pelo prejuízo, que, no entanto, terá direito a ação regressiva para haver a importância que tiver ressarcido ao lesado. De igual modo ocorre quando existente responsabilidade contratual de transportador (art. 735 do CC), que pagará pelos danos e terá direito a ação regressiva.

\section{Incapacidade civil do causador do dano}

O Código Civil trata da questão da responsabilidade do incapaz nos seguintes artigos 928 e 934, in fine:

Artigo 928. O incapaz responde pelos prejuízos que causar, se as pessoas por ele responsáveis não tiverem obrigação de fazê-lo ou não dispuserem de meios suficientes. 
Parágrafo único. A indenização prevista neste artigo, que deverá ser eqüitativa, não terá lugar de privar do necessário o incapaz ou as pessoas que dele dependem.

Artigo 934. Aquele que ressarcir o dano causado por outrem pode reaver o que houver pago daquele por quem pagou, salvo se o causador do dano for descendente seu, absoluta ou relativamente incapaz.

Nota-se inovação com relação à responsabilização do próprio incapaz por danos causados a terceiros, ampliando o rol dos responsáveis civis.

São também responsáveis pela reparação civil: os pais, pelos filhos menores (crianças ou adolescentes) que estiverem sob sua autoridade e em sua companhia; e, o tutor e o curador, pelos pupilos e curatelados, que se acharem nas mesmas condições.

Aúnica hipótese em que poderá haver responsabilidade solidária do menor de 18 anos com seus pais é ter sido emancipado nos termos do art. $5^{\circ}$, parágrafo único, inc. I, do novo Código Civil. (NEGRÃO; GOUVÊA, 2007a ou b??, p. 255).

O incapaz passa a responder com seu próprio patrimônio pelos prejuízos que causar, se as pessoas por ele responsáveis não tiverem obrigação de fazê-lo ou não dispuserem de meios suficientes. A indenização, nesses casos, deverá ser eqüitativa e não terá lugar se privar do necessário o incapaz ou as pessoas que dele dependem.

A impossibilidade de privação do necessário à pessoa, prevista no art. 928, traduz um dever de indenização eqüitativa, informado pelo princípio constitucional da proteção à dignidade da pessoa humana. Como conseqüência, também os pais, tutores e curadores serão beneficiados pelo limite humanitário do dever de indenizar, de modo que a passagem ao patrimônio do incapaz se dará não quando esgotados todos os recursos do responsável, mas se reduzidos estes ao montante necessário à manutenção de sua dignidade. (NEGRÃO; GOUVÊA, 2007a, p. 255).
O incapaz responde pelos prejuízos que causar de maneira subsidiária, porque, a priori, a obrigação recai sobre o responsável, que responde independentemente de culpa (art. 933 do CC), a não ser que este não tenha obrigação de fazê-lo.

Vê-se que constitui uma modalidade diferenciada da aplicação da teoria do risco.

Exime-se de tal obrigação o responsável legal quando provar qualquer das causas excludentes da responsabilidade, porque rompem com o nexo de causalidade até mesmo para os casos da aplicação da teoria objetiva.

\section{Responsabilidade Civil e o Código de Trânsito Brasileiro - Lei 9.503, de 23.09.1997.}

Em decorrência do número de bens a serem protegidos em decorrência de um acidente de trânsito, a lei precisou abarcar essas novas situações e dar amparo normativo ao direito preexistente.

Felizmente, após trinta e um anos de vigência, o vetusto Código Nacional de Trânsito (Lei 5.108, de 21.09.1966) foi substituído pelo atual Código de Trânsito Brasileiro (lei 9.503, de 23.09.1997), que trouxe inúmeras modificações e inovações, inclusive contendo um capítulo exclusivo para os delitos de trânsito (STOCO, 2004, p. 1374).

As regras que disciplinam o trânsito de qualquer natureza nas vias terrestres do território nacional regem-se pelo Código de Trânsito Brasileiro (Lei 9.503, de 23.09.1997), que entrou em vigor em 22.01.98.

A responsabilidade administrativa e penal do motorista está contida nesse Código de Trânsito. As infrações administrativas estão previstas nos arts. 161 a 255 e as penalidades por infração às regras estabelecidas para a circulação de veículos automotores situam-se nos arts. 256 a 268 . Os crimes de trânsito encontram-se nos arts. 291 a 312.

As mais expressas modificações introduzidas 
pelo CTB se deram na área criminal e foram severamente criticadas pela Doutrina, já que apresentaram uma incongruência desastrosa com as disposições do Código Penal vigente, no que diz respeito à tipificação do crime e penalidade.

Por outro lado, a parte criminal do código preocupou-se com a reparação do dano civil, fazendo da composição prevista na lei dos Juizados Especial Criminal uma forma de extinção da punibilidade em alguns crimes de trânsito, como, por exemplo, lesão corporal culposa e embriaguez ao volante (art. 291 do CTB), enquadrando-os como de menor potencial ofensivo.

A transação civil do artigo 74 da Lei 9.9099/95 homologada pelo Juízo tem força de título executivo, a ser executado pelo Ministério Público. Caso não haja a transação entre autor e vítima, o Ministério Público pode oferecer a transação penal, quando cumpridos os requisitos do art. $76, \S 2^{\circ}$, da Lei 9.099/95, que prevê a aplicação de multa, valor que reverte em favor da vítima (art. 297, caput, do CTB).

Nestes casos, a composição do dano material será abreviada, com enorme vantagem, posto que a multa poderá ter valor inferior ou igual ao prejuízo patrimonial experimentado, mas de todas as maneiras, será descontado na Ação Civil buscada pela vítima, que poderá nem existir.

O cálculo da multa é baseado no $\S 1^{\circ}$ do artigo 49 do Código Penal, conforme dispõe o artigo 297 do CTB e o teto limite é de 306 dias-multa ou R\$ $324.000,00$.

Logo, a multa adquiriu uma natureza dúplice: pena criminal e sanção civil.

Se na audiência de conciliação: 1) não houver transação civil (acordo reparatório do dano material entre as partes), 2) o réu não aceitar a transação penal proposta pelo Ministério Público ou 3) não puder valer-se dela (requisitos do artigo 76, $\$ 2^{\mathrm{a}}$, da Lei 9.099/95), ainda assim o réu estará sujeito à aplicação de multa, isolada ou concomitantemente com a pena restritiva de liberdade, quando o crime assim previr.

Esta multa prevista no tipo penal também será revertida em favor da vítima. Por exemplo: no crime do artigo 305 (fuga do local do acidente) a multa é alternativa ("ou") com a pena restritiva de liberdade, mas no crime do artigo seguinte, 306 (embriaguez), a multa é concomitante ("e").

Logo, dificilmente a vítima verá encerrado um processo criminal sem qualquer reparação, pois somente nos artigos 302 (homicídio culposo) e 303 (lesão corporal culposa) que o legislador não previu aplicação de multa e, pela cominação máxima da pena (3 e 2 anos respectivamente), não se aplica o artigo 76 da Lei 9.099/95, ou seja, transação civil e penal.

Quanto ao crime de lesão corporal, vislumbra-se uma incongruência com os artigos correspondentes a ele no Código Penal e CTB.

Isto porque o crime de lesão culposa do artigo $129, \S 6^{\circ}$, do CP, independente da gravidade da lesão, tem pena máxima cominada de um ano, ou seja, enquadra-se no rol dos crimes de menor potencial ofensivo, que prevê a aplicação de transação civil e penal.

Já o Código de Trânsito Brasileiro, em seu artigo 303, para o mesmo delito de lesão culposa, agora na direção de veículo automotor, prevê pena máxima de 2 anos, tempo que ultrapassa o limite estabelecido pela Lei 9.099/95, o que impede a indenização civil pelo réu no juízo criminal à vítima.

Neste caso, o Superior Tribunal de Justiça, até 2001, aplicava a Lei 9.099/95 (vide RHC 10872), lei mais benéfica ao réu. Com o advento da Lei do Juizado Especial Federal, que elevou a pena máxima para 2 anos, o STJ passou a aplicar os benefícios do juizado aos delitos estaduais com esta pena máxima, em atenção ao princípio da isonomia (vide RESP. 610328, RESP. 610323 e HC 25901).

Em suma, apenas quando não há acordo ou nos casos dos artigos 302 (homicídio culposo) e 303 
(lesão corporal culposa) do CTB é que o prejudicado necessariamente deverá ajuizar a competente ação reparatória no juízo cível, porque não haverá tal possibilidade no juízo criminal.

Para esses casos, permanece a legislação civil para aferição do quantum indenitário.

No caso de homicídio o Código Civil estabelece:

"Art. 948. No caso de homicídio, a indenização consiste, sem excluir outras reparações:"

"I - no pagamento das despesas com o tratamento da vítima, seu funeral e o luto da família;"

"II - na prestação de alimentos às pessoas a quem o morto os devia, levando-se em conta a duração provável da vida da vítima.”

Também lesão corporal encontra previsão específica:

“Art. 949. No caso de lesão ou outra ofensa à saúde, o ofensor indenizará o ofendido das despesas do tratamento e dos lucros cessantes até ao fim da convalescença, além de algum outro prejuízo que o ofendido prove haver sofrido".

Note-se que a responsabilidade civil é independente da criminal salvo nas hipóteses previstas no art. 935 do Código Civil, quando há discussão em torno da existência do fato ou quem seja o seu autor. Ensina o mestre José de Aguiar Dias que:

A reparação civil reintegra, realmente, o prejudicado na situação patrimonial anterior (pelo menos tanto quanto possível, dada a falibilidade da avaliação); a sanção penal não oferece nenhuma possibilidade de recuperação ao prejudicado; sua finalidade é restituir a ordem social ao estado anterior à turbação. (DIAS, 1979, p. 11).
O Código de Trânsito prevê o instituto da multa reparatória nos casos em que há condenação por crime, que ocasionou prejuízo material à vítima ou aos seus sucessores, hipótese em que o juiz poderá aplicá-la. Regulamente o CTB:

Art. 297. A penalidade de multa reparatória consiste no pagamento, mediante depósito judicial em favor da vítima, ou seus sucessores, de quantia calculada com base no disposto no $\S 1^{\circ}$ do art. 49 do Código Penal, sempre que houver prejuízo material resultante do crime.

“§ $1^{\circ} \mathrm{A}$ multa reparatória não poderá ser superior ao valor do prejuízo demonstrado no processo."

“\$ $2^{\circ}$ Aplica-se à multa reparatória o disposto nos arts. 50 a 52 do Código Penal."

“ $\$ 3^{\circ} \mathrm{Na}$ indenização civil do dano, o valor da multa reparatória será descontado."

Importa ressaltar que o dano moral não se inclui na multa reparatória, devendo ser pleiteado pelas vias próprias, pois o artigo 297 do CTB refere-se apenas à ocorrência de "prejuízo material resultante de crime".

No âmbito da responsabilidade civil o Código de Trânsito pouco disciplinou, predominando as prescrições do Código Civil, a construção doutrinária e jurisprudencial de uma maneira geral, aplicada ao trânsito.

Como, apesar da juventude, as normas nele adotadas são insuficientes para resolver as multifárias questões que surgem a cada momento, carreou-se, mais uma vez, ao Poder Judiciário a difícil missão de assentar as premissas básicas da obrigação de indenizar nos casos de acidentes decorrentes da circulação de veículos, razão pela qual multifária é a jurisprudência que se formou em curto espaço de tempo, enriquecendo sobremaneira os repositórios de precedentes jurisprudenciais. (STOCO, 2004, p. 1376).

Ainda assim, deve-se ter em mente que não há como as leis preverem todas as situações jurídicas 
com o objetivo de impedir o acidente, pois mesmo respeitando todas as regras de trânsito o motorista está sujeito a fatos externos, cuja responsabilidade ainda pode ser a ele atribuída, porque goza da coisa.

\section{Conclusão}

O trabalho discute os aspectos mais intrigantes e debatidos da responsabilidade civil em acidentes de trânsito à luz da legislação pertinente ao tema, interpretada pela doutrina e jurisprudência.

Pode-se extrair da leitura do texto os pressupostos para aferição da culpa e se encontrar os parâmetros para determinação do quantum indenitário, mediante o estudo das normas prescritas no Código Civil associadas aos artigos do Código de Trânsito Brasileiro.

Sob a ótica acurada dos Tribunais, é possível verificar a dinamicidade com que a matéria tem se amoldado à realidade atual, que retrata um aumento expressivo no número de acidentes envolvendo veículos automotores.

A diversidade dos casos oriundos de acidentes com automóveis premiu da doutrina e jurisprudência uma variedade de soluções legais para as relações jurídicas criadas entre vítima, condutor, responsável legal, incapaz, semoventes, segurado, seguradora, beneficiário, Estado e terceiros interessados.

É certo que um acidente de trânsito desencadeia uma série de fatos jurídicos que formam uma teia de conseqüências legais que pode interligar, em um único caso, todas estas pessoas num só processo.

A dificuldade mais evidente, então, fica por conta da produção da prova da culpa e da extensão do dano. Nesse ponto, leva-se em conta o grau da culpa ou existência de dolo na conduta do agente, bem como o tipo do dano e sua intensidade, se dano material, moral ou estético e a valoração correspondente. Comumente se verifica a necessidade de prova pericial em determinada coisa ou pessoa.
A norma processual, portanto, distribui às partes o ônus ou incumbência de produzir determinada prova, sob pena de se estabelecer à presunção legal da culpa ou dano.

A indenização pelos prejuízos causados é medida pelo juiz na sentença, tendo por critério o que foi produzido na instrução processual, podendo ser determinada na forma de prestação pecuniária, pensão, obrigação de fazer ou outra convencionada pelas partes, contanto que não encontre vedação legal.

Portanto, em matéria de responsabilidade civil em acidentes de trânsito, o Direito atende às peculiaridades do caso concreto, pois, com base na legislação, interpretada pela doutrina e jurisprudência, é efetivo em dirimir os conflitos ocasionados pelos sinistros, de forma a conceder aos jurisdicionados a devida prestação jurídica.

\section{Referências}

BRASIL. Constituição (1988). Constituição da República Federativa do Brasil de 1988. Disponível em: <http://www.planalto.gov.br/ccivil_03/Constituicao/ Constitui\%C3\%A7ao.htm>. Acesso em 29 ago. 2007.

BRASIL. Lei 9.503, de 23 de setembro de 1997. Institui o Código de Trânsito Brasileiro. Diário Oficial [da] República Federativa do Brasil, Brasília. Disponível em: $<$ http://www.planalto.gov.br/ccivil_03/leis/L9503.htm>. Acesso em 29 ago. 2007.

BRASIL. Superior Tribunal de Justiça. Ag 142796. Disponível em: <http://www.stj.gov.br/webstj/processo/ Justica/detalhe.asp?numreg $=199700206149 \& p v=01000$ 0000000\&tp=51>. Acesso em 29 ago. 2007.

. AgRg 769719. Disponível em: < http://www.stj. gov.br/SCON/jurisprudencia/doc.jsp?livre $=$ dano + est $\% \mathrm{E}$ 9 tico + dano + moral $\& \& b=$ ACOR $\& \mathrm{p}=$ true $\& \mathrm{t}=\& \mathrm{l}=10 \& \mathrm{i}=$ 7>. Acesso em: 29 ago. 2007.

AgRg no Ag 731148. Disponível em: < http:// www.stj.gov.br/SCON/jurisprudencia/doc.jsp?livre=den uncia $\% \mathrm{E} 7 \% \mathrm{E} 3 \mathrm{o}+\mathrm{a}+$ lide + obrigatoriedade $\& \& \mathrm{~b}=\mathrm{ACOR} \&$ $\mathrm{p}=$ true $\& \mathrm{t}=\& \mathrm{l}=10 \& \mathrm{i}=5>$. Acesso em: 29 ago. 2007.

REsp 256424. Disponível em: < http://www.stj. gov.br/SCON/jurisprudencia/doc.jsp?livre $=\mathrm{a} \% \mathrm{E} 7 \% \mathrm{E} 3 \mathrm{o}$ + direta + contra $+\mathrm{a}+$ seguradora $\& \& b=A C O R \& p=$ true $\& \mathrm{t}=$ $\& \mathrm{l}=10 \& \mathrm{i}=1>$. Acesso em: 29 ago. 2007. 
REsp 261310. Disponível em: <http://www.stj. gov.br/webstj/processo/Justica/detalhe.asp?numreg=20 $0000536857 \& p v=010000000000 \& \mathrm{tp}=51>$. Acesso em: 29 ago. 2007.

REsp 264119. Disponível em: < http://www.stj. gov.br/webstj/processo/Justica/detalhe.asp?numreg=200 $000616311 \& p v=010000000000 \& t p=51>$. Acesso em 29 ago. 2007.

REsp 275453. Disponível em: < http://www.stj. gov.br/SCON/jurisprudencia/doc.jsp?livre=a\%E7\%E3 $\mathrm{o}+$ direta + contra $+\mathrm{a}+$ seguradora $+\mathrm{n} \% \mathrm{E} 3 \mathrm{o}+$ cabimento \& \& $\mathrm{b}=\mathrm{ACOR} \& \mathrm{p}=$ true $\& \mathrm{t}=\& \mathrm{l}=10 \& \mathrm{i}=2>$. Acesso em 29 ago. 2007.

REsp 309283. Disponível em: < http://www.stj. gov.br/SCON/jurisprudencia/doc.jsp?livre=denuncia $\% \mathrm{E}$ $7 \%$ E3o $+\mathrm{a}+$ lide $+\mathrm{t} \%$ EDtulo + executivo $\& \& b=$ ACOR $\& \mathrm{p}=\mathrm{t}$ rue $\& \mathrm{t}=\& \mathrm{l}=10 \& \mathrm{i}=4>$. Acesso em: 29 ago. 2007.

. REsp 435865. Disponível em: <http://www.stj. $\overline{\text { gov.br/webstj/processo/Justica/detalhe.asp?numreg }=20}$ $0200653487 \& \mathrm{pv}=010000000000 \& \mathrm{tp}=51>$. Acesso em: 29 ago. 2007.

. REsp 591729. Disponível em: <http://www.stj. gov.br/SCON/jurisprudencia/doc.jsp?livre=dano+pessoa $1+$ ministro + barros + monteiro $\& \& b=$ ACOR $\& p=$ true $\& t=\&$ $1=10 \& \mathrm{i}=3>$. Acesso em: 29 ago. 2007.

REsp. 294057. Disponível em: < http://www.stj. gov.br/SCON/jurisprudencia/doc.jsp?livre $=\mathrm{a} \% \mathrm{E} 7 \% \mathrm{E} 3 \mathrm{o}$ + direta + contra $+\mathrm{a}+$ seguradora $\& \& \mathrm{~b}=\mathrm{ACOR} \& \mathrm{p}=$ true $\& \mathrm{t}=$ $\& \mathrm{l}=10 \& \mathrm{i}=4>$. Acesso em 29 ago. 2007.
BRASIL. Supremo Tribunal Federal. Súmula $n^{\circ} 188$. Disponível em: <http://www.stf.gov.br/\#>. Acesso em: 29 ago. 2007.

. Súmula $n^{\circ} 246$. Disponível em: <http://www.stf. gov.br/\#>. Acesso em: 29 ago. 2007.

. Súmula $n^{\circ} 43$. Disponível em: <http://www.stf. gov.br/\#>. Acesso em: 29 ago. 2007.

. Súmula $n^{\circ}$ 54. Disponível em: <http://www.stf. gov.br/\#>. Acesso em: 29 ago. 2007.

DIAS, J. A. Da responsabilidade civil. 6. ed. Rio de Janeiro: Forense, 1979.

MÁRIO, C. Responsabilidade civil. 3. ed. Rio de Janeiro: Forense, 1992.

NEGRÃO, T.; GOUVÊA, J. R. F. Código civil elegislação civil em vigor. 26. ed. São Paulo: Saraiva, 2007a.

Código de processo civil e legislação processual em vigor. 39. ed. São Paulo: Saraiva, $2007 \mathrm{~b}$.

REIS, C. Avaliação do dano moral. 3. ed. Rio de Janeiro: Forense. 2000.

RODRIGUES, S. Direito civil: responsabilidade civil. 15. ed. São Paulo: Saraiva. 1997. v. 4.

SILVA, W. M. Da responsabilidade civil automobilística. 4. ed. São Paulo: Saraiva, 1983.

STOCO, R. Tratado de responsabilidade civil. 5. ed. São Paulo: RT, 2001.

Tratado de Responsabilidade Civil. 6. ed. São Paulo: RT, 2004. 